\title{
RETRACTION
}

\section{Retraction Notice to : Expression of MRTF-A and AQP1 Play Important Roles in the Pathological Vascular Remodeling}

Asian Pac J Cancer Prev, 16 (6), 2587

\section{Yong Jiang}

At my request the paper entitled 'The Expression of MRTF-A and AQP1 Play Important Roles in the Pathological Vascular Remodeling'Asian Pac J Cancer Prev, 16, 1375-83 has been retracted. The reason was a charge of plagiarism with regard to the paper entitled 'Reciprocal expression of MRTF-A and myocardin is crucial for pathological vascular remodelling in mice' published earlier in EMBO Journal (EMBO J. 2012 Nov 28;31(23):4428-40. doi: 10.1038/emboj.2012.296. Epub 2012 Oct 26.). I am very sorry that this occurred but I sincerely believe this was due to negligence on the part of the translation company that I trusted to make my manuscript ready for submission.

Laboratory Medical College, Jilin Medical College, Jilin, P.R.China For correspondence: jiangyongpost@sina.com 